\title{
Hubungan antara kecemasan dan keterbukaan diri dalam pergaulan sehari-hari remaja di Karang Taruna Setiabudi Jakarta
}

\author{
Nurbaiti Nurbaiti $^{{ }^{*}}$, Miskanik Miskanik ${ }^{2)}$, Veno Dwi Krisnanda ${ }^{3)}$ \\ 1,2,3) Universitas Indraprasta PGRI \\ ") utari2525@gmail.com
}

Article History: Received: 03/08/2021; Revised: 19/10/2021; Accepted: 22/10/2021 Published: 30/10/2021.

How to cite: Nurbaiti, N., Miskanik, M., \& Krisnanda, V.D. (2021). Hubungan antara kecemasan dan keterbukaan diri dalam pergaulan sehari-hari remaja di Karang Taruna Setiabudi Jakarta. Orien: Cakrawala Ilmiah Mahasiswa, 1(2), pp. 129-134. DOI: 10.30998/ocim.v1i2.4844

(c) (i) This is an open distributed under the Creative Commons 4.0 Attribution License, which permits unrestricted use, distribution, and reproduction in any medium, provided the original work is properly cited. (c) 2021, Nurbaiti, Miskanik, \& Krisnanda.

\begin{abstract}
Abstrak: Tujuan dari penelitian ini dimaksud untuk mengetahui tentang hubungan antara kecemasan dan keterbukaan diri. Metode penelitian yang digunakan adalah kuantitatif korelasional. Teknik sampling yang digunakan adalah sampling jenuh. Instrument yang digunakan dalam penelitian ini dalah angket. Teknik Analisa data dilakukan dengan uji korelasi, uji regresi linear sederhana dan uji hipotesis. Hasil penelitian disimpulkan secara umum bahwa terdapat hubungan antara kecemasan dan keterbukaan diri di Karang Taruna Setiabudi Jakarta dan menghasilkan hubungan yang negatif. Yang artinya semakin tinggi tingkat kecemasan maka semakin rendah tingkat keterbukaan diri remaja, dan sebaliknya semakin rendah tingkat kecemasan maka semakin tinggi tingkat keterbukaan diri.
\end{abstract}

Kata Kunci: kecemasan, keterbukaan diri

\begin{abstract}
The purpose of this research is to find out about the relationship between anxiety and self-disclosure. The research method used correlational quantitative. The sampling technique used is saturated sampling. The instrument used is a questionnaire. The techniques data analysis is done by correlation test, simple linear regression test and hypothesis test. The results of the research that there was a relationship between anxiety and self-disclosure at Karang Taruna Setiabudi Jakarta and resulted in a negative relationship. Which means that the higher the level of anxiety, the lower the level of self-disclosure of adolescents, and conversely the lower the level of anxiety, the higher the level of self-disclosure.
\end{abstract}

Keywords: anxiety, self-disclosure

\section{Pendahuluan}

Manusia merupakan makhluk sosial, yang dimana dalam kehidupannya membutuhkan kehadiran sosok individu lainnya diberbagai situasi atau kondisi. Untuk dapat menjalani kehidupan sebagai makhluk sosial yang baik tentu diperlukan suatu komunikasi. Komunikasi merupakan suatu hal yang dasar yang tidak dapat terpisah dari kehidupan manusia, dengan komunikasi yang baik, diharapkan dapat menjembatani interaksi antar individu satu sama lain.

Komunikasi yang efektif dapat terjadi, yaitu ketika masing-masing individu dapat merasa berhasil menyampaikan pesan kepada lawan bicaranya dan salah satu kuncinya yaitu adanya keterbukaan antara kedua belah pihak, keterbukaan diri menjadi dasar dalam komunikasi agar tidak terjadi kesalahpahaman atau hal-hal yang tidak diinginkan nantinya. Pada kenyataanya banyak sekali individu pada saat ini tidak terbuka mengungkapkan mengenai informasi tentang dirinya, perasaannya, dan lain sebagainya. Perasaan takut tidak diterima oleh 
kelompok atau lingkungan membuat individu tidak terbuka mengenai dirinya hingga menimbulkan kecemasan.

Kaplan, Sadock, dan Grebb (Fausiah \& Widury, 2007) Menyatakan bahwa kecemasan adalah respon terhadap situasi tertentu yang mengancam, dan merupakan hal yang normal terjadi menyertai perkembangan, perubahan pengalaman baru atau yang belum pernah dilakukan, serta dalam menemu kan identitas diri dan arti hidup.

Untuk menghindari timbulnya perasaan cemas akan tidak diterimanya individu di dalam sebuah kelompok atau lingkungan, tentu hal yang dapat individu lakukan yaitu dengan keterbukaan diri. Dengan membuka diri tak jarang pula diantara mereka saling mengenal lebih mendalam satu sama lain. Sebagai makhluk yang membutuhkan kehadiran orang lain, manusia tentu perlu membangun kedekatan dengan manusia lainnya. Kedekatan itu dapat dimulai dengan adanya keterbukaan diri melalui komunikasi. Hubungan tidak akan dapat terjalin secara dekat atau intim jika tidak dimulai dengan keterbukaan.

Menurut Liliweri (Silfia, 2017) mengatakan bahwa "Membuka diri adalah awal dari terjadinya kontak pribadi, relasi pertama yang menghubungkan orang dengan orang lain". Menurut Morton (Hidayat, 2012), keterbukaan diri merupakan suatu kegiatan membagi perasaan dan informasi yang akrab dengan individu lain. Informasi pengungkapan diri ini bersifat deskriptif dan evaluatif.

Masa remaja adalah masa dimana individu sering dihadapkan pada situasi dimana individu dituntut untuk lebih banyak mengambil keputusan, menyelesaikan konflik dan membangun atau memperbaiki hubungan dengan orang lain. Dimasa-masa remaja juga peran seorang teman yang mengerti mengenai kondisi kita juga sangat diperlukan, untuk itu kita perlu mengungkapkan mengenai diri kita ke orang lain. Sebenarnya, kecemasan merupakan hal yang sangat lumrah di rasakan oleh siapapun, karena itu merupakan sebuah respon terhadap suatu situasi yang dianggap mengancam atau membahayakan. Apalagi ketika seseorang dituntut untuk melakukan pengungkapan diri pada individu yang baru tentu rasa atau tingkat kecemasan itu akan semakin tinggi dikarenakan individu tersebut merasa berda pada situasi yang kurang nyaman.

Dalam pergaulan sehari-hari remaja tentu terdapat sebuah hubungan komunikasi yang terbangun antar indiviu satu dengan individu lainnya. Untuk menghasilkan suatu pola komunikasi yang baik tentunya harus didasarkan oleh adanya hubungan yang transparan, dan jelas. Artinya remaja dalam pergaulan sehari-hari harus melakukan keterbukaan diri agar hubungan yang dijalinnya dapat bersifat lebih nyata. Namun, hal itu bukanlah sebuah perkara mudah untuk dilakukan dalam pergaulan remaja karena adanya faktor kecemasan atau rasa takut tidak diterima oleh kelompok, sehingga terkadang membuat remaja tidak mau membuka dirinya bahkan cenderung menutupi hal yang mungkin tidak ingin diketahui oleh orang lain.

Sebuah penelitian yang dilakukan oleh Gainau (2009) menunjukan bahwa individu yang mampu melakukan pengungkapan diri dengan tepat, terbukti mampu menyesuaikan diri (adaptive), lebih memiliki rasa percaya diri, lebih kompeten, dapat diandalkan, mampu bersikap positif, percaya terhadap orang lain, lebih objektif dan terbuka. Keadaan sebaliknya, individu yang kurang mampu dalam melakukan pengungkapan diri akan timbul perasaan takut, cemas, merasa rendah diri, dan tertutup.

Seperti halnya yang terjadi di Karang Taruna Setiabudi, Menurut data yang peneliti dapatkan bahwa memang ada beberapa individu (remaja) yang masih belum mau terbuka ketika berlangsungnya sebuah kegiatan yang dilakukan. Seperti misalnya masih banyak yang enggan mengungkapkan pemikiran atau ide ketika kegiatan rapat. Hal ini terjadi diantaranya karena adanya perasaan cemas, tidak percaya diri sehingga membuat beberapa individu di dalam 
Karang Taruna Setiabudi masih menutup diri. Hal biasa yang dilakukan untuk mengentaskan rasa cemas yang dirasakan oleh anggota (remaja) di karang taruna tersebut yang dilakukan oleh ketua karang taruna tersebut ialah dengan mengarahkan anggota untuk mengeksplor dirinya sehingga membuka diri secara tidak langsung.

Tujuan dari penelitian ini adalah untuk mencari tahu adakah hubungan antara kecemasan dan keterbukaan diri dalam kehidupan sehari-hari remaja di Karang Taruna Setiabudi Jakarta. Dan juga membuktikan hipotesis atau dugaan sementara yang telah peneliti buat yaitu hipotesis pertama bahwa kecemasan memiliki hubungan dengan keterbukaan diri $\left(\mathrm{H}_{1}\right)$. Sedangkan hipotesis kedua bahwa kecemasan tidak memiliki hubungan dengan keterbukaan diri $\left(\mathrm{H}_{0}\right)$.

\section{Metode}

Penelitian ini menggunakan pendekatan kuantitatif yang bersifat pengaruh, yaitu untuk mengetahui adanya pengaruh dari variabel independen terhadap variabel dependen. Metode kuantitatif dengan pendekatan korelasional ini dipilih karena sesuai dengan tujuan penelitian yang ingin dicapai, yakni ingin mengetahui apakah terdapat pengaruh antara kecemasan dan keterbukaan diri dalam kehidupan sehari-hari remaja. Teknik sampling yang digunakan adalah Teknik sampling jenuh. Karena jumlah populasi peneliti kurang dari 100, maka sample yang digunakan oleh peneliti adalah seluruh anggota karang taruna Setiabudi sebanyak 43 responden. Selain jumlah anggota yang sedikit, dikarenakan kondisi pandemi membuat peneliti sulit untuk mendaptkan izin dan responden yang banyak.

Instrumen penelitian yang digunakan dalam penelitian ini yaitu angket kuesioner yang terdiri dari 50 butir pernyataan. Angket kuesioner tersebut terdiri dari aitem-aitem pertanyaan yang telah sesuai dengan variabel yang hendak diukur, dimana terdapat 25 aitem untuk variabel kecemasan dan 25 aitem untuk variabel keterbukaan diri. Sebelumnya peneliti juga telah melakukan judgement kepada ahli dan melakukan uji validitas serta reliabilitas. Skala yang digunakan dalam angket kuesioner ini adalah Skala Likert dengan alternatif jawaban Sangat Setuju (SS), Setuju (S), Tidak Setuju (TS), Sangat Tidak Setuju (STS).

Penelitian ini dilaksanakan kurang lebih selama 4 bulan. Terhitung dari bulan April hingga Juli 2021 dengan berbagai tahapan-tahapan. Mulai tahap persiapan, tahap pengumpulan data dan tahap analisis data.

Pengolahan analisis data ini menggunakan Uji Korelasi untuk mengetahui hubungan kedua variabel. Uji Regresi Linear Sederhana untuk mengetahui sejauh mana hubungan sebab akibat antara variabel independen terhadap variabel dependen Serta menggunakan Uji T dan Uji F untuk menguji hipotesis yang telah dibuat.

\section{Hasil dan Diskusi}

Berdasarkan hasil analisis penelitian yang dilakukan berdasarkan data yang ada, yaitu Dalam pergaulan sehari-hari remaja tentu terdapat sebuah hubungan komunikasi yang terbangun antar indiviu satu dengan individu lainnya. Untuk menghasilkan suatu pola komunikasi yang baik tentunya harus didasarkan oleh adanya hubungan yang transparan, dan jelas. Artinya remaja dalam pergaulan sehari-hari harus melakukan keterbukaan diri agar hubungan yang dijalinnya dapat bersifat lebih nyata. Namun, hal itu bukanlah sebuah perkara mudah untuk dilakukan. 
Kecemasan menjadi salah satu faktor yang membuat seorang individu atau remaja sukar untuk membuka dirinya, perasaan cemas karena takut tidak diterima di dalam kelompoknnya, akhirnya membuat remaja terkadang menutup diri atau bahkan memanipulasi mengenai keadaan dirinya agar diterima dengan baik di lingkungan kelompoknya.

Salah satu dari tujuan penelitian ini adalah untuk mengetahui adakah hubungan antara kecemasan dan keterbukaan diri remaja dalam kehidupan sehari-hari, setelah melakukan penyebaran instrumen penelitian dan melakukan analisis data dengan menggunakan uji korelasi.

\begin{tabular}{llll}
\multicolumn{4}{c}{$\begin{array}{c}\text { Tabel 1. Uji Korelasi } \\
\text { Correlations }\end{array}$} \\
\hline Kecemasan & \multicolumn{1}{c}{ Kecemasan } & Keterbukaan diri \\
\hline & Pearson Correlation & 1 & $-.559^{* *}$ \\
Keterbukaan diri & Sig. (2-tailed) & & .000 \\
& $\mathrm{~N}$ & 43 & 43 \\
& Pearson Correlation & $-.559^{* *}$ & 1 \\
& Sig. (2-tailed) & .000 & 43 \\
\hline
\end{tabular}

**. Correlation is significant at the 0.01 level (2-tailed).

Berdasarkan tabel 1 dapat diketahui bahwa terdapat hubungan antara kecemasan sebagai variabel $(X)$ dengan keterbukaan diri sebagai variabel $(Y)$. dimana ditunjukan dengan nilai -.559. yang artinya kedua hubungan antar variabel tersebut bersifat negatif. Semakin tinggi tingkat kecemasan maka akan semakin rendah tingkat keterbukaan diri seseorang, begitu pula sebaliknya semakin rendah tingkat kecemasan maka semakin tinggi tingkat keterbukaan diri seseorang.

Untuk mengetahui seberapa kuat pengaruh dari kecemasan dan keterbukaan diri terhadap remaja dalam kehidupan sehari-hari, dapat dilihat dari koefisien determinasi (R square) yaitu sebesar 0,312 atau jika diubah kedalam bentuk persen menjadi 31,2\%.

Tabel 2. Hasil Uji Regresi Linear Sederhana

\begin{tabular}{crrrrc}
\multicolumn{6}{c}{ Model Summary } \\
\hline Model & $\mathrm{R}$ & & R Square & Adjusted R Square & Std. Error of the Estimate \\
\hline & 1 & $.559^{\mathrm{a}}$ & .312 & .295 & 4.675 \\
\hline
\end{tabular}

a. Predictors: (Constant), Kecemasan

Berdasarkan hasil uji normalitas terhadap variabel kecemasan dan keterbukaan diri diperoleh nilai Kolmogrov-Smirnov sebesar 0,809>0,05. Hasil tersebut menunjukan bahwa sebaran data kecemasan terhadap keterbukaan diri memiliki distribusi normal. Uji linearitas hubungan antara variabel kecemasan dengan keterbukaan diri remaja menghasilkan nilai signifikan 0,481 > 0,05, hasil tersebut menunjukan bahwa hubungan antara variabel kecemasan dengan keterbukaan diri adalah memiliki hubungan yang linear.

Hal tersebut juga diperkuat dengan hasil yang diperoleh dari hasil pengujian hipotesis yang menunjukan bahwa nilai sig lebih kecil dari taraf siginifikan $(0,000<0,005)$, yang 
menyatakan bahwa terdapat pengaruh antara kecemasan dan keterbukaan diri, sehingga hipotesis $\left(\mathrm{H}_{0}\right)$ yang dibuat peneliti dapat diterima.

Tabel 3. Hasil Uji Hipotesis

Coefficients ${ }^{\mathrm{a}}$

\begin{tabular}{|c|c|c|c|c|c|c|c|}
\hline & & & dardized & Coefficients & $\begin{array}{l}\text { Standardized } \\
\text { Coefficients }\end{array}$ & & \\
\hline & Model & B & & Std. Error & Beta & & Sig. \\
\hline 1 & (Constant) & & 87.305 & 5.205 & & 16.774 & .000 \\
\hline & Kecemasan & & -.382 & .089 & -.559 & -4.313 & .000 \\
\hline
\end{tabular}

a. Dependent Variable: Keterbukaan diri

Seperti yang telah diuraikan di atas, bahwa ada hubungan antara kecemasan dengan keterbukaa diri. Karena salah satu faktor yang membuat individu sulit untuk membuka diri yaitu kecemasan. Perasaan cemas atau takut akan peristiwa yang akan datang dan mungkin tidak akan terjadi, akhirnya membuat banyak remaja menutup dirinya. Permasalahan-permasalahan tersebut sepertinya banyak terjadi di lingkungan pergaulan remaja, kadang kala tidak sedikit pula remaja yang memutuskan untuk membuka diri, namun dengan cara fiktif sehingga memanipulasi agar dapat diterima di lingkungan pergaulannya.

Hasil penelitian ini secara teknis dapat dijadikan dasar dalam pengembangan penelitian lanjutan bagi penelitian yang berkaitan dengan kecemasan dan keterbukaan diri remaja. Meskipun responden dalam penelitian ini bukanlah siswa (peserta didik) namun, penelitian ini juga dapat dilakukan atau diterapkan pada guru BK untuk mengetahui mengenai tingkat kecemasan dan keterbukaan diri peserta didik sehingga dapat membangun suatu pola komunikasi yang transparan antara siswa satu dengan siswa lainnya.

Peneliti menyadari bahwa penelitian ini belum sempurna, dan memiliki keterbatasan diantarnya yaitu hasil penelitian ini belum tentu dapat di generalisasikan kepada karang taruna lainnya. Karena, setiap individu tentu memiliki pernyataan yang berlainan. Untuk itu peneliti berharap adanya penelitian lanjutan untuk menyempurnakan hasil penelitian ini.

\section{Simpulan}

Berdasarkan hasil penelitian dan pembahasan yang peneliti lakukan tentang hubungan antara kecemasan dan keterbukaan diri dalam kehidupan sehari-hari remaja di Karang Taruna Setiabudi Jakarta bahwasanya terdapat pengaruh antara kecemasan dan keterbukaan diri dalam kehidupan sehari-hari remaja di Karang Taruna Setiabudi Jakarta dan menghasilkan hasil hubungan yang negatif, dimana ditunjukan dengan nilai -0.559. yang artinya semakin tinggi tingkat kecemasan, maka tingkat keterbukaan diri akan semakin rendah. Dan begitu sebaliknya jika tingkat kecemasan rendah, maka tingkat keterbukaan diri akan tinggi.

\section{Ucapan Terima Kasih}

Terimakasih peneliti ucapkan kepada berbagai pihak yang telah membantu dalam menyelesaikan penelitian ini, yang merupakan salah satu syarat untuk mendapatkan gelar sarjana. Terimakasih kepada Dosen Pembimbing Materi dan Teknik, serta para Dosen lainnya yang selama empat tahun telah memberikan ilmunya. Terimakasih kepada orang tua dan 
134 Hubungan antara kecemasan dan keterbukaan diri dalam pergaulan sehari-hari remaja di Karang Taruna Setiabudi Jakarta

keluarga telah menjadi support system bagi peneliti dan tentunya teman-teman yang terus memberikan dukungan. Sehingga peneliti berhasil menyelesaikan penelitian ini.

\section{Daftar Rujukan}

Fausiah, F., \& Widury, J. (2007). Psikologi Abnormal. Universitas Indonesia, Jakarta.

Gainau, M. B. (2009). Keterbukaan diri (self disclosure) siswa dalam perspektif budaya dan implikasinya bagi konseling. Jurnal Ilmiah Widya Warta, 33(1), 95-112.

Hidayat, D. (2012). Komunikasi Antarpribadi dan Medianya: Fakta penelitian fenomenologi orang tua karir dan anak remaja. -.

Silfia, H. (2017). Komunikasi Antarpribadi: Teori dan Praktik. Ar-Ruzz media.

\section{Competing interests:}

The authors declare that they have no significant competing financial, professional or personal interests that might have influenced the performance or presentation of the work described in this manuscript. 